\section{Arylacethydroxamic Acids: a New Class of Potent Non-steroid Anti-inflammatory and Analgesic Substances}

IN recent years much effort has been directed to the search for non-steroid anti-inflammatory substances which can be used in the therapy of rheumatic diseases and related conditions ${ }^{1}$. This communication reports the finding that a chemical family hitherto unexplored in this respect, namely, the arylacethydroxamic acids, includes several substances endowed with considerable anti-inflammatory and analgesic properties, and also a remarkably low degree of toxicity. A particularly interesting compound in this series was 4-butoxy-3-methylphenylacethydroxamic acid (I). In a comparative in-<smiles>CCCCOc1ccc(CC(=O)NO)cc1[N+](=O)[O-]</smiles>

(I)<smiles>CCCOc1ccc(CC(N)=O)cc1</smiles>

(II)

vestigation with known antiphlogistic compounds, using the Benitz and Hall carrageenin-induced abscess test in rats $^{2}$, compound (I), in exactly the same dose, proved only slightly less active (c. half) than phenylbutazone (1,2-diphenyl-3,5-diketo-4-butylpyrazolidine), definitely more active than 'Ibufenac' ( $p$-isobutylphenylacetic acid), and considerably more so than aspirin. The activity shown by compound (I) at the high dosage of $1 \mathrm{~g} / \mathrm{kg}$ was as intense as that of the maximum tolerated dose of phenylbutazone $(400 \mathrm{mg} / \mathrm{kg})$ and considerably more so than that $(10 \mathrm{mg} / \mathrm{kg})$ of 'Indomethacin' (1- $p$-chlorobenzoyl-5-methoxyindolyl-3-acetic acid), which is the most efficient non-steroid antiphlogistic substance known so far. Compound (I) was also strongly active in the carrageenin-induced granuloma test in rats, whereas phenylbutazone and aspirin are known to behave poorly in this type of assay ${ }^{3}$.

Analgesic activity, determined in mice by means of Blake's test involving an electric stimulus ${ }^{4}$, indicated that compound $(\mathbf{I})$ was considerably more effective than the non-morphinic reference analgesics: the 50 per cent effective doses, measured after $90 \mathrm{~min}$, were:
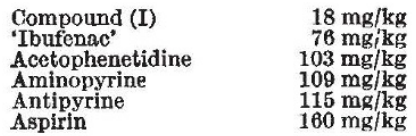

Comparative determination of acute toxicity in mice with known anti-inflammatory agents gave the following figures for the 50 per cent lethal dose:

$\begin{array}{lr}\text { Compound (I) } & 1,800 \mathrm{mg} / \mathrm{kg} \\ \text { Aspirin } & 1,100 \mathrm{mg} / \mathrm{kg} \\ \text { Phenylbutazone } & 290 \mathrm{mg} / \mathrm{kg} \\ \text { 'Indomethacin" } & 26 \mathrm{mg} / \mathrm{kg}\end{array}$

Chronic oral toxicity tests performed in compound (I) in both rats and dogs produced no signs of toxicity at $125 \mathrm{mg} / \mathrm{kg}$ and per day.

The relationships between chemical structure and pharmacodynamic activity are evidenced in the data given in Table 1 for compounds chosen from among several hundred investigated.

Table 1

\begin{tabular}{|c|c|}
\hline Activit & \\
\hline Anti-inflammatory & Analgesic \\
\hline $\begin{array}{l}++++ \\
++++\end{array}$ & $\begin{array}{l}+++t \\
+++t\end{array}$ \\
\hline - & \\
\hline - & \\
\hline $\begin{array}{c}++ \\
+\end{array}$ & $t+t$ \\
\hline \pm & $+t$ \\
\hline \pm & ++ \\
\hline $\begin{array}{c}++ \\
\pm\end{array}$ & \\
\hline - & + \\
\hline- & - \\
\hline$\overline{-}$ & $++t+$ \\
\hline- & $+t+$ \\
\hline
\end{tabular}

The most interesting features to emerge from Table 1 are: $(a)$ the complete disappearance of anti-inflammatory activity encountered in passing from 4-butoxyphenylacethydroxamic acid to 4-butoxyphenylacetic acid itself, thus pointing to a specific influence on the part of the hydroxamic acid function; $(b)$ the discrepancy observed between the anti-inflammatory and analgesic activitiesan extreme example being 4-butoxyphenylacetamide (II), the total inactivity of which as an anti-inflammatory agent contrasts strikingly with its remarkable analgesic potency, which is roughly the same as that of compound (I) (its 50 per cent effective dose being $17 \mathrm{mg} / \mathrm{kg}$ ); 4 butoxyphenylacetamide, and 4-butoxyphenylacethydroxamic acid, also show antipyretic effects (in rabbits in a state of hyperthermia induced by injection of antityphoid vaccine $\mathrm{TAB}$ ) comparable with that of aspirin; $(c)$ the close dependence of anti-inflammatory activity on the number, nature, and site of the substituents on the aryl nucleus, a striking example being the absence of activity of 4-butoxy-2,3-dimethylphenylacethydroxamic acid, as compared with the outstanding activity of its lower homologue, compound (I). Further replacement of the nuclear methyl group in (I) by bromine, chlorine $\odot$ fluorine results in comparably active compounds.

It is doubtless relevant to the mechanism of the antiinflammatory action of compound (I) and its homologues that, on one hand, adrenalectomy inhibits their effects and, on the other hand, investigations made in rats with carbon-14-labelled 4-butoxyphenylacethydroxamic acid showed high levels of radioactivity in the adrenals. trial.

Compounds (I) and (II) are both undergoing clinical

Institut du Radium,

N. P. BuU-Hoï

26 rue d'Ulm,

Paris (Ve), France.

\section{G. LAMBELiN \\ C. GILLET \\ C. LepoIvre \\ J. Thiriaux \\ G. MeEs}

Research Laboratories,

Continental Pharma,

Machelen (Brabant),

Belgium.

1 See, for example, Shen, T. Y., Windholz, T. B., Rosegay, A., Witzel, B. E., Wilson, A. N., Willett, J.'D., Holtz, W. J., Fllis, R. T.., Matzuk, A. R., Lucas, S., Stammer, C. H., Holy, F. W., Sarett, T. H., Risley, A. A., Nuss, G. W., and Winter, C. A., J. Amer. Chem. Soc., 85, 488 (1963); Winder, C. V., Wax, J., Querubin, B. S., Jones, E. M., and McPhee, M. L., Arthr. and Rheum., 6, 36 (1963); Delbarre, F., Buu-Hol, N. P., Jacquignon, P., Brouilhet, II., Kahan, A., and Marty, M., Medicina Experimentalis,

Benitz, K. F., and Hall, L. M., Aroh. Intern. Pharmacodyn., 144, 185 (1963). 3 See Whitehouse, M. W., in Progress in Drug Research, 8, 321 (1965).

- Blake, L., Graene, M. L., and Sigg, E. B., Medioina Experimentalis, 9, 146 (1963).

' Results evaluated according to the method of Litchfield and Wilcoxson; see, for example, Litchfleld, J. T., The Evaluation of Drug Toxicity (Churchill, London, 1958). 